\title{
ANALISIS PRAKTEK PERWAKAFAN UANG PADA LEMBAGA KEUANGAN SYARIAH
}

\author{
Ahmad Furqon \\ IAIN Walisongo Semarang \\ e-mail: matfurqon@yahoo.co.id
}

\begin{abstract}
Waqf of money curently become focus of interest among Muslim community. One of the banks executed the waqf of money is BSM. Some conclusions drawn from this research: (1) Information dissemination on waqf of money is still relatively limited compared to the wealth of medium and experiences that the bank had, (2) BSM has no specific counter for giving services, so any customer visiting the bank for applying waqf of money, customer service and the officials of the bank will serve them, without the nāzir, and witness present; and (3) Two models of investation of the waqf of money in bank: riil sector for building mother and child hospital, and financial sector, in which the money was deposited in Deposito Syariah Mandiri.

$* * *$

Waqf uang saat ini menjadi fokus kajian yang menarik di kalangan masyarakat Islam. Salah satu bank yang menjalankan waqf uang adalah BSM. Ada beberapa kesimpulan yang dapat ditarik dari kajian ini: (1) Penyebaran informasi waqf uang masih relatif terbatas dibandingkan dengan kekayaan media dan pengalaman yang dimiliki oleh bank, (2) BSM tidak memiliki meja khusus yang dapat melayani pelanggan yang datang ke bank untuk mendaftarkan waqf uang sehingga ketika pelanggan datang untuk mendaftarkan waqf uang petugas layanan pelanggan dan petugas bank akan melayani mereka tanpa nadzir dan saksi; dan (3) Dua model investasi wakaf uang di bank: sektor riil untuk pembangunan rumah bersalin, dan sektor finansial, di mana uang didepositkan dalam Deposito Syariah Mandiri.
\end{abstract}

Keywords: $\quad$ wakaf uang, nāzirir, investasi, tabungan 


\section{A. Pendahuluan}

Salah satu ciri khas perwakafan uang pasca terbitnya Undang-Undang Wakaf No.41 Tahun 2004 adalah ditunjuknya Lembaga Keuangan Syariah Sebagai Lembaga Penerima Wakaf Uang. KH. Tholchah Hasan selaku ketua Badan Wakaf Indonesia, dalam jumpa pers setelah ditetapkannya lima bank syariah sebagai Lembaga Keuangan Syariah Penerima Wakaf Uang (LKSPWU) oleh Menteri Agama, menyatakan bahwa setelah ditetapkannya LKSPWU, maka perwakafan uang harus lewat bank-bank syariah yang telah ditetapkan sebagai LKS-PWU tersebut. ${ }^{1}$

Berdasarkan Keputusan Menteri Agama No. 92-96 Tahun 2008, ditunjuk lima bank syariah sebagai LKS-PWU, yaitu Bank Syariah Mandiri, Bank Muamalat Indonesia, Bank Nasional Indonesia (BNI) Syariah, Bank Mega Syariah dan Bank DKI Syariah. ${ }^{2}$ Keputusan Menteri Agama ini sesuai dengan amanat yang tertera di dalam pasal 28 UU No. 41 Tahun 2004 tentang Wakaf. ${ }^{3}$

Dipilihnya bank-bank syariah dalam menerima wakaf uang dikarenakan secara umum perbankan syariah memiliki beberapa keunggulan yang diharapkan dapat mengoptimalkan operasional wakaf uang tersebut, diantaranya: (1) Jaringan kantor cabang yang tersebar di seluruh provinsi, kabupaten maupun kota. Dengan relatif luasnya jaringan kantor perbankan diharapkan akan lebih mengefektifkan sosialisasi wakaf uang kepada masyarakat, sehingga penggalangan dana wakaf menjadi lebih optimal dan juga membantu efektivitas dan efisiensi penyampaian dana wakaf kepada al-Mawqūf 'alaih; (2) Kemampuan sebagai fund manager, lembaga perbankan merupakan lembaga yang memiliki pengalaman dalam mengelola dana masyarakat dan juga berpengalaman sebagai lembaga perantara surplus spending unit dengan deficit spending unit, dengan pengalaman tersebut, apabila perbankan syariah diamanatkan untuk mengelola wakaf uang, tentunya hal tersebut dapat dengan cepat dilaksanakan karena pengalaman yang telah dimiliki tersebut; (3) Pengalaman, jaringan informasi dan peta distribusi. Sebagai pengelola dana untuk kemudian disalurkan kepada pihak tertentu, lembaga

\footnotetext{
${ }^{1}$ http://portalantara.co.id/berita/1252575568/wakaf-harus-uang-melalui-bank-syariah

${ }^{2}$ http://www.republika.co.id/berita/36558/Peran_LKS_di_Era_Wakaf_Produktif

${ }^{3}$ Isi Pasal 28 adalah: wāqif dapat mewakafkan benda bergerak berupa uang melalui Lembaga Keuangan Syari'ah yang ditunjuk oleh Menteri.
} 
perbankan memiliki pengalaman, informasi serta peta ditribusi ke mana dana-dana tersebut dapat disalurkan. Dalam praktek operasional selanjutnya, ketiga hal tersebut menjadi faktor yang akan selalu dipertimbangkan di dalam mengoptimalkan pengelolaan dana, ${ }^{4}$ dan (4) Bank memiliki kredibilitas di mata masyarakat dan dikontrol dengan perundang-undangan yang berlaku. Bank syariah seharusnya merupakan lembaga yang shariah high regulated karena dipantau oleh Dewan Syariah Nasional (DSN) dan Dewan Pengawas Syariah (DPS). Dengan adanya pemantauan ini dapat menghindarkan bank syariah dari kesalahan pengelolaan wakaf uang.

Difungsikannya bank syariah sebagai lembaga pengelola dana wakaf merupakan manifestasi dari fungsi keharusan sebuah bank untuk mengelola tiga sektor pelanggan ekonomi, yaitu formal, nonformal dan voluntary sektor. ${ }^{5}$ Hal ini terinspirasi dengan berdirinya Social Investment Bank Limited (SIBL) di Bangladesh, yang menjalankan fungsi bank di sektor voluntary dengan menghimpun dana dari para nasabah yang kaya dalam bentuk penawaran Certificate Cash Waqf untuk program-program sosial.

Penunjukkan bank-bank syariah sebagai LKS-PWU menjadikan posisi bank-bank LKS-PWU menjadi penting dalam kesuksesan program wakaf uang. Berhasilnya tidaknya penghimpunan dan pengelolaan wakaf uang bergantung pada kinerja yang dilakukan oleh LKS-PWU tersebut.

Selain pertimbangan positif yang telah disebutkan di atas ada hal-hal lain yang perlu menjadi perhatian yang dapat menghambat kesuksesan bank-bank syariah dalam mengelola wakaf uang, diantaranya: (1) Posisi bank-bank LKSPWU yang hanya sebagai "penerima," menjadikan bank tidak mengambil sikap aktif dalam menjaring wāqif karena mereka tidak dapat menentukan bentukbentuk pengelolaan untuk wakaf uang yang diterima dan peruntukannya bagi siapa. Hal ini juga berpengaruh pada sosialisasi yang diberikan kepada masyarakat, sosialisasi menjadi tidak produktif karena bank-bank syariah tidak mampu menjelaskan peruntukan wakaf uang yang telah dikumpulkan tersebut; (2) Proses sosialisasi penggalangan dana wakaf yang membutuhkan

${ }^{4}$ Biro Perbankan Syariah BI dalam Mustofa Edwin dan Uswatun Hasanah (ed.), Wakaf Tunai Inovasi Finansial Islam, Peluang dan Tantangan dalam Mewujudkan Kesejahteraan Umat (Jakarta: PSTTI-IU, 2001), h. 105-106.

${ }^{5}$ Dir. Pemberdayaan Wakaf, Strategi Pengembangan Wakaf Tunai di Indonesia (Jakarta: Dir. Pemberdayaan Wakaf Departemen Agama, 2008), h. 37. 
biaya besar sehingga terkadang perbankan syariah terkendala dengan masalah dana tersebut; (3) Bank sebagai lembaga keuangan yang memiliki citra profit oriented belum bisa memposisikan dirinya pada saat yang sama sebagai lembaga keuangan yang juga berorientasi sosial sehingga orientasi sosial tersebut kurang menjadi perhatian dan (4) Faktor SDM yang ada dalam LKSPWU dalam mengelola wakaf uang. Oleh karena itu tujuan yang ingin dicapai dalam penelitian adalah untuk mengetahui bentuk penggalangan dana yang dilakukan oleh LKS-PWU Bank Syariah Mandiri, mekanisme perwakafan uang yang dilakukan oleh LKS-PWU Bank Syariah Mandiri, dan mengetahui bentuk investasi wakaf uang di LKS-PWU Bank Syariah Mandiri.

Penelitian ini dilakukan di Bank Syariah Mandiri, Penelitian tentang wakaf dapat dimasukkan dalam bidang penelitian hukum Islam dan pranata sosial. Namun jika dilihat dari sudut tempatnya penelitian ini termasuk penelitian lapangan atau kancah, yakni penelitian yang mengandalkan data dari masyarakat yang diteliti. ${ }^{6}$ Lapangan yang dimaksud dalam penelitian ini adalah Bank Mandiri Syariah. Penelitian ini adalah penelitian kualitatif yang mendasarkan datanya dari wawancara dengan informan yang terpilih. Adapun subjek penelitiannya adalah para pengelola Bank Syariah Mandiri. Pengumpulan data dalam penelitian ini menggunakan beberapa teknik, yaitu: (1) Studi Kepustakaan dan dokumentasi; (2) Observasi, teknik ini digunakan untuk mengamati secara langsung dan seksama subjek penelitian dan (3) Wawancara. ${ }^{7}$

\section{B. Perwakafan Uang di LKS-PWU Bank Syariah Mandiri}

\section{Profil PT. Bank Syariah Mandiri}

PT. Bank Syariah Mandiri (BSM) pada mulanya bernama PT. Bank Suslila Bakti (BSB) yang diakuisisi oleh PT. Bank Mandiri Persero sebagai pemilik saham mayoritas pada bank tersebut dan kemudian dikonversi dari statusnya sebagai Bank Konvensional menjadi Bank Syariah sebagai respon dari terbitnya UU No. 10 tahun 1998, yang memberi peluang bank umum untuk melayani transaksi syariah (dual banking system). Pendirian PT. Bank Syariah Mandiri

${ }^{6}$ Suharsimi Arikunto, Prosedur Penelitian, Suatu Pendekatan Praktik, (Jakarta: Rineka Cipta, 2006), h. 8-9.

${ }^{7}$ Soerjono Soekanto, Pengantar Penelitian Hukum, (Jakarta: UI Press, 1986), h. 230-231. 
berdasarkan Akta Notaris: Sutjipto, SH, No. 23 tanggal 8 September 1999. Pada awal berdiri BSM Memiliki modal Rp. 1.000.000.000.000. sedangkan modal disetor berjumlah: Rp. Rp. 658.243.565.000,-. BSM memiliki 390 kantor layananan yang tersebar di 30 provinsi di Indonesia, dengan 4.544 orang karyawan. Komposisi kepemilikan saham BSM adalah: (1) PT. Bank Mandiri (Persero) Tbk.: 131.648 .712 lembar saham (99,999999\%) dan (2) PT. Mandiri Sekuritas: 1 lembar saham $(0,000001 \%)^{8}$

BSM memiliki berbagai macam produk jasa perbankan, yang berbentuk pendanaan, pembiayaan dan layanan. Produk Pendanaan berbentuk: BSM Tabungan, BSM Tabungan Berencana, BSM Tabungan Simpatik, BSM Tabungan Mabrur, BSM Tabungan Investa Cendekia, BSM Tabungan Deposito, BSM Valas, BSM Giro, BSM Giro Valas, BSM Giro Singapore Dollar, BSM Giro Euro, BSM Obligasi, dan BSM Tabungan Perusahaan.

Produk Pembiayaan berbentuk: BSM Pembiayaan Mudharabah, BSM Pembiayaan Musyarakah, BSM Pembiayaan Murabahah, BSM Pembiayaan Talangan Haji, BSM Pembiayaan Istișna', Pembiayaan dengan Skema IMBT (Ijarah Muntahiyah Bit Tamlik), Pembiayaan Mudharabah Muqayyadah of Balance Sheet, BSM Customer Networking Financing, BSM Pembiayaan Resi Gudang, BSM Pembiayaan Edukasi, BSM Optima Pembiayaan Pemilikan Rumah, Pembiayaan Pemilikan Rumah Syariah (PPRS) Bersubsidi, Pembiayaan Umroh, Pembiayaan Kepada Pensiun, Pembiayaan Peralatan Kedokteran, PKPA, BSM Implan, Pembiayaan Dana Berputar, BSM Sistem Pembayaran off line, dan Pembiayaan Dengan Agunan Investasi Terikat Syariah Mandiri.

Produk Layanan berbentuk: BSM Card, BSM Sentra Bayar, BSM Mobile Banking, BSM Net Banking, BSM Pertukaran Valas, BSM Bank Garansi, BSM Electronic Payroll, SKBDN, BSM Kliring, BSM Inkaso, BSM Intercity Clearing, BSM RTGS, BSM Mobile Banking, BSM Mobile Banking GPRS, BSM Pooling Fund, BSM Letter of Credit, BSM Transfer Valas, BSM Reksadana Mandiri Investa Berimbang, dan Layanan Penerimaan Pembayaran Premi Asuransi Takaful. ${ }^{9}$ Hingga 31 Desember 2009, kinerja keuangan Bank Syariah Mandiri dapat dijelaskan pada tabel 1 berikut: 10

8 http://www.syariahmandiri.co.id/category/info-perusahaan/profil-perusahaan/ diakses tanggal 23 Agustus 2010, dan Laporan Tahun 2009 PT. Bank Syariah Mandiri, h. 7.

${ }^{9}$ Laporan Tahunan 2009 PT. Bank Syariah Mandiri, h. 20-23.

${ }^{10}$ Ibid., h. 6. 
Tabel 1.

Kinerja Keuangan Bank Mandiri per 31 Desember 2009

\begin{tabular}{cll}
\hline No & Keterangan & Jumlah \\
\hline 1 & Total Aset & Rp. 22.036.534.515.115 \\
2 & Dana Pihak Ketiga & Rp. 19.338 Triliun \\
3 & Pembiayaan yang diberikan & Rp. 16.063 Triliun \\
4 & Laba bersih & Rp. 291 Miliar \\
5 & Pembiayaan terhadap dana pihak & $83,07 \%$ \\
& ketiga & \\
6 & CAR & $12,39 \%$ \\
\hline
\end{tabular}

Sumber: Laporan Tahunan 2009 PT. Bank Syariah Mandiri

Selain mengelola dana masyarakat yang bersifat formal dan nonformal, Bank Syariah Mandiri juga mengelola dana dari sektor voluntary atau mengelola modal sosial yang berasal dari dana masyarakat dalam bentuk Zakat, Infak, Sedekah dan Wakaf (ZISWAF) dengan membentuk Yayasan Bangun Sejahtera Mitra Ummat (BSM Ummat) yang salah satu unit usaha yayasan tersebut adalah Lembaga Amil Zakat (LAZ) BSM Ummat. LAZ BSM menghimpun dana ZISWAF yang berasal dari karyawan Bank Syariah Mandiri dan masyarakat. Pada laporan keuangan per akhir Desember 2009 LAZ BSM memiliki saldo kas dan Bank sebesar Rp. 11.434.225.508,43 jumlah tersebut terdiri atas beberapa jenis dana yang dijelaskan pada tabel 2 berikut:

Tabel 2.

Perkembangan Dana ZISWAF LAZ BSM Tahun 2008 - 2009

\begin{tabular}{|c|c|c|c|}
\hline No & Jenis Dana & 2009 & 2008 \\
\hline 1 & Dana Zakat & 6.420.465.009,69 & 4.464.941.984,52 \\
\hline 2 & Dana Infaq & 2.205.476.182,66 & 1.381.209.657,08 \\
\hline 3 & Dana Sosial & 1.132.256.019,46 & $420.509 .333,88$ \\
\hline 4 & Dana Kemanusiaan & $870.122 .569,88$ & $103.601 .531,44$ \\
\hline 5 & Dana Pengelola & 268.786.244,96 & $229.020 .678,11$ \\
\hline 6 & Dana Qurban & $200.000,00$ & $200.000 ., 00$ \\
\hline 7 & Dana Wakaf & 290.378.077,60 & $247.475 .111,42$ \\
\hline \multirow[t]{2}{*}{8} & Dana iB CSR & $246.541 .404,18$ & \\
\hline & Total & 11.434.225.508,43 & 6.846.958.296,45 \\
\hline
\end{tabular}

Sumber: LAZBSM Tahun 2010 
Dana yang dihimpun LAZ BSM didistribusikan pada beberapa program unggulan LAZ BSM, antara lain: (1) Program Mitra Umat: berfokus pada pemberdayaan umat melalui bantuan modal kerja yang disalurkan kepada pedagang kecil atau usaha kecil-mikro (UKM); (2) Program Didik Umat: berfokus kepada penyaluran bantuan biaya pendidikan atau beasiswa kepada anak-anak kaum dִu'afä' atau yang berhak menerima zakat agar bisa melanjutkan sekolah dan (3) Program Simpati Umat: berfokus pada kegiatan yang bersifat charity, di antaranya: bantuan atau dana zakat yang digulirkan secara langsung kepada 8 golongan yang berhak menerima zakat, maupun masyarakat yang tidak memiliki biaya untuk berobat atau korban bencana alam. ${ }^{11}$

Terlihat dalam tabel penerimaan dana sosial dan ZISWAF tahun 2009, LAZ BSM Umat menerima dana wakaf sebesar Rp. 290.378.077,60. Dalam menerima dan pengelolaan dana wakaf ini LAZ BSM bukan sebagai LKS-PWU akan tetapi sebagai nāẓir yang menerima, mengelola dan mendistribusikan hasil dari dana wakaf tersebut

\section{Bank Syariah Mandiri sebagai LKS-PWU}

Pasca terbitnya UU No.41 Tahun 2004 tentang Wakaf, BSM mengajukan permohonan sebagai Lembaga Keuangan Syariah Penerima Wakaf Uang (LKS-PWU) kepada Menteri Agama dan disahkan sebagai LKS-PWU berdasarkan Keputusan Menteri Agama Nomor. 95 tahun 2008. Sejak diterbitkannya Surat Keputusan penunjukkan sebagai LKS-PWU, BSM bekerjasama dengan Badan Wakaf Indonesia (BWI) mulai melakukan praktek penerimaan wakaf uang. ${ }^{12}$

Pada laporan nāzirir BWI per-30 Juni 2010, BSM tercatat telah menghimpun dana wakaf uang sebesar Rp. 852.093.873,18 dengan jumlah 1922 wāqif. Sedangkan LKS-PWU yang lain sebagai berikut:13

11 http://www.syariahmandiri.co.id/2010/05/laporan-keuangan-laz-2/, diakses pada tanggal 23 Agustus 2010.

12 Wawancara dengan Sri Handiyani, staf pada Direktorat Tresuri dan Jaringan PT. Bank Syariah Mandiri, tanggal 6 Agustus 2010, jam 16.00-16.30.

${ }^{13}$ Laporan Nazhir Badan Wakaf Indonesia Per-30 Juni 2010. 
Tabel 3.

Dana Yang dihimpun Bank Syariah Mandiri Per 30 Juni 2010

\begin{tabular}{clc}
\hline No & \multicolumn{1}{c}{ Keterangan } & \multicolumn{1}{c}{ Jumlah } \\
\hline 1 & BNI Syariah Acc.333000 003 & Rp. 311.526 .579 .00 \\
2 & Bank Muamalat Acc.3012345615 & Rp. 48.775 .620 .59 \\
3 & Bank DKI Syariah Acc.701 7003939 & Rp. 111.215 .300 .00 \\
4 & Bank Mega Syariah Acc. 10000.11111 & Rp. 102.893.865.00 \\
\hline
\end{tabular}

Sumber: Bank Syariah Mandiri, 2010

Dana wakaf uang yang dihimpun PT. Bank Syariah Mandiri per-Juni 2010 meningkat dibandingkan per-Februari 2010, yaitu berjumlah Rp. 647.008.399. Dana wakaf uang yang telah dihimpun tersebut disimpan dalam rekening Badan wakaf Indonesia yang merupakan nāzir dari wakaf uang tersebut.

\section{Bentuk Fundraising Dana Wakaf Uang di LKS-PWU Bank Syariah Mandiri}

Fundraising adalah suatu kegiatan penggalangan dana dari induvidu, organisasi maupun badan hukum. Fundraising juga merupakan proses mempengaruhi masyarakat (calon wāqif) agar mau melakukan amal kebajikan dalam bentuk penyerahan uang sebagai wakaf maupun untuk sumbangan pengelolaan harta wakaf.

LKS-PWU juga berkewajiban untuk melakukan fundraising dana wakaf kepada masyarakat dengan memberitahukan kepada masyarakat statusnya sebagai LKS-PWU. Hal tersebut berdasarkan Pasal 25 PP No. 42 Tahun 2006 menyatakan: LKS-PWU bertugas mengumumkan kepada publik atas keberadaannya sebagai LKS Penerima Wakaf Uang.

BSM selaku LKS-PWU telah melakukan penggalangan dana wakaf uang dengan mengumumkannya kepada masyarakat dalam bentuk menyebarkan promosi tentang wakaf uang. Akan tetapi promosi tersebut baru dalam bentuk yang minim yaitu sebatas pengadaan brosur wakaf uang yang ditempatkan di BSM Cabang ataupun Bank Cabang Pembantu. Pemasangan brosur tersebut baru di BSM yang berada disekitar Jakarta saja, sedangkan di daerah-daerah, media promosi tentang wakaf uang tersebut belum tersedia.

Sebenarnya banyak media promosi yang dapat digunakan Bank Syariah Mandiri untuk menginformasikan statusnya sebagai LKS-PWU. Misalnya 
lewat iklan di media massa seperti televisi, radio atau surat kabar. Atau lewat internet dengan mencantumkan program wakaf tunai tersebut di website Bank Syariah Mandiri. ${ }^{14}$ Hal tersebut tentunya bukan merupakan suatu yang sulit bagi Bank Syariah Mandiri karena BSM telah memiliki website resmi di internet. Akan tetapi ternyata promosi tentang wakaf uang tidak ditemukan dalam website Bank Syariah Mandiri. Dalam fitur produk jasa ataupun layanan Bank Syariah Mandiri belum ditemukan layanan penerimaan wakaf uang di Bank tersebut selaku LKS-PWU.15 Selain media promosi tersebut, BSM dapat juga melakukan sosialisasi wakaf uang lewat event festival, malam amal, dll. Akan tetapi hal tersebut belum dilakukan oleh BSM.

Sosialisasi BSM kepada masyarakat untuk wakaf uang relatif lambat. Informasi tentang wakaf uang hanya di temukan di kantor pusat BSM dan kantor-kantornya yang beroperasi di Jakarta saja. Sedangkan di daerah, sosialisasi BSM sebagai LKS-PWU belum terlaksana. Hal tersebut bisa dibuktikan dengan tidak adanya brosur tentang wakaf uang di bank-bank tersebut ${ }^{16}$, dan belum adanya instrumen untuk pelaksanaan akad wakaf uang seperti Akta Ikrar Wakaf dan Sertifikat Wakaf Uang

Kondisi BSM yang minim melakukan sosialisasi sebagai LKS-PWU walaupun sebenarnya BSM dapat dengan mudah mensosialisasikannya karena telah memiliki penggalaman dalam fundraising dana masyarakat selain wakaf, dan telah memiliki media sosialisasi program, disebabkan karena beberapa hal, antara lain: (1) Status BSM sebagai unit bisnis yang bekerja untuk meraih keuntungan yang maksimal, memandang program wakaf uang bukanlah program yang akan mendatangkan banyak keuntungan sehingga terkalahkan dengan produk lain yang lebih mendatangkan banyak keuntungan. Dalam kondisi demikian, biaya sosialisasi untuk produk tersebut akan ditekan seminim mungkin yang berimbas pada kurangnya sosialisasi untuk produk tersebut; (2) Belum ada devisi yang khusus mengurus masalah wakaf uang di BSM. Saat sekarang ini wakaf uang ditangani oleh devisi Tresuri dan

\footnotetext{
${ }^{14} \mathrm{http}: / /$ www.syariahmandiri.co.id/

${ }^{15}$ Lihat produk layanan dan jasa Bank Syariah Mandiri h.1-2 makalah ini. lihat pula di www.syariahmandiri.co.id.

${ }^{16}$ Pernyataan Agus Setiawan (Customer Service Officer BSM Cabang Semarang), tanggal 27 Agustus 2010, jam 10.00-10.30., dan Muhammad Irham (Staf Marketing BSM Cabang Bengkulu, tanggal 25 Agustus 2010, jam 15.00-15.30).
} 
Perbankan Internasional. ${ }^{17}$ Sebelum diterbitkannya peraturan wakaf uang harus di LKS-PWU, calon wāqif diarahkan kepada LAZ BSM Umat. Karena tidak adanya devisi khusus menyebabkan program wakaf kurang menjadi prioritas sebab program tersebut ditumpangkan kepada devisi yang memiliki program yang berbeda dengan wakaf uang sehingga terkesan promosi wakaf uang di BSM sangat kurang dan lambat dan (3) Status LKS-PWU BSM yang hanya sebagai bank penerima menjadikan BSM tidak terlalu aktif dalam fundraising. Karena yang paling bertanggungjawab terhadap fundraising tersebut adalah nāzirir wakaf uang yang dalam hal ini adalah BWI.

Walaupun BSM masih minim melakukan sosialisasi wakaf uang akan tetapi BSM dapat menjadi LKS-PWU dengan penghimpunan dana terbesar, hal tersebut dapat terjadi karena: Pertama. Walaupun amanat undangundang mengharuskan BSM selaku LKS-PWU untuk mengumumkan statusnya sebagai LKS-PWU akan tetapi promosi wakaf uang lebih banyak dilakukan oleh nāzir wakaf uang yaitu Badan Wakaf Indonesia. Banyaknya calon wāqif yang melakukan wakaf uang adalah karena promosi wakaf uang yang dilakukan oleh BWI. BWI telah melakukan berbagai macam metode fundraising wakaf uang, diantaranya: pencanangan Gerakan Nasional Wakaf Uang, meluncurkan website BWI (www.bwi.or.id), publikasi wakaf di media massa (cetak dan online), Talk show sosialisasi wakaf di televisi dan sosialisasi wakaf produktif ke ormas-ormas Islam. ${ }^{18}$

Kedua. Keberadaaan BSM sebagai bank nasional yang telah dikenal masyarakat dan memiliki kantor-kantor jaringan tersebar diseluruh Indonesia menguntungkan BSM, karena menjadi pilihan utama bagi calon wāqif untuk berwakaf. Sehingga BSM merupakan LKS-PWU dengan pengumpulan harta wakaf terbanyak. ${ }^{19}$ Dari segi layanan yang dimiliki oleh BSM untuk wāqif agar dapat berwakaf uang, BSM baru menempuh dua layanan: pertama, layanan langsung yaitu wāqif secara langsung datang ke BSM untuk penyetoran wakaf uang, kedua, layanan tidak langsung yaitu transfer rekening näzir BWI.20

\footnotetext{
${ }^{17}$ Wawancara dengan Sri Handiyani, tanggal 6 Agustus 2010 jam 16.30-17.00.

18 http://www.bwi.or.id/index.php?option=com_content\&view=article\&id=654\%3 Abwi-rayakanhari-jadi-ketiga\&catid=1\%3Aberitawakaf\&Itemid=134\&lang=in, diakses pada tanggal 16 Agustus 2010 .

${ }^{19}$ Lihat: Laporan Nazhir Badan Wakaf Indonesia per 30 Juni 2010.

${ }^{20}$ Wawancara dengan Nasep (staf BSM Kantor Cabang Kelapa Gading Jakarta), tanggal 20 Agustus 2010, lihat juga brosur wakaf uang yang dikeluarkan oleh BSM.
} 
Adapun penyetoran tidak langsung via layanan BSM yang lain seperti: pembayaran via phone banking, pembayaran via ATM, pembayaran via SMS, pembayaran via internet belum dilakukan karena instrumen pembayaran wakaf uang seperti yang disebutkan di atas belum diaktifkan oleh BSM untuk penerimaan wakaf uang.

Sebenarnya BSM telah memiliki layanan bertransaksi menggunakan media electronic channel selain transfer ATM tersebut, akan lebih baik apabila BSM mengaktifkan layanan-layanan tersebut agar hasil penghimpunan dana wakaf uang dapat lebih masif, karena layanan tidak langsung memberikan kemudahan bagi calon wāqif yang tidak memiliki waktu untuk datang langsung ke BSM.

Hal tersebut semakin mendesak untuk disediakan oleh BSM karena Pasal 6 ayat (3) Peraturan Badan Wakaf Indonesi (BWI) No. 1 Tahun 2009 tentang Setoran Wakaf Tunai Tidak Langsung menyatakan: LKS-PWU wajib menyiapkan sistem online penerimaan wakaf uang yang menggunakan media electronic channel, yang di dalamnya mengandung informasi antara lain sebagai berikut: (1) Daftar nama nāẓir yang akan dipilih wāqif; (2) Daftar denominasi wakaf uang; (3) Formulir penyataan kehendak wāqif yang berfungsi sebagai AIW dan (4) Persetujuan setoran wakaf uang yang telah diikrarkan.

Karenanya layanan bertransaksi berbasis electronic banking harusnya lebih digalakkan dengan keanekaragamannya seperti: pembayaran via phone banking, pembayaran via ATM, pembayaran via kartu debet, pembayaran via internet atau pembayaran via SMS.

\section{Mekanisme Perwakafan Uang di LKS-PWU Bank Syariah Mandiri}

Mekanisme perwakafan uang di BSM dilakukan dengan dua cara, yaitu: (1) perwakafan langsung; (2) perwakafan tidak langsung. Pertama, dalam perwakafan langsung, calon wāqif mendatangi BSM Pusat. Ketika calon wāqif menyatakan kehendaknya untuk berwakaf uang, ia akan ditemui oleh bagian customer service (CS) BSM Pusat. Lalu CS memberikan kepada calon wāqif. Formulir Wakaf Uang yang berfungsi sebagai Akta Ikrar Wakaf (AIW), yang diisi terlebih dahulu oleh calon wāqif disertai dengan fotocopy kartu identitas diri yang berlaku. Selanjutnya calon wāqif menyetorkan nominal wakaf uang dan mengisi formulir transfer uang ke rekening BWI selaku nāzir wakaf uang, 
dengan nomor rekening: 00900 1234. Selanjutnya wāqif mengucapkan șigat wakaf uang sebagaimana yang tertera dalam Akta Ikrar Wakaf yang telah diisi. Setelah proses pembacaan șigat wakaf dan penandatanganan selesai, BSM mencetak Sertifikat Wakaf Uang (SWU) dan menyerahkannya kepada wāqif beserta Formulir Wakaf Uang yang berfungsi sebagai Akta Ikrar Wakaf (AIW), selanjutnya salinan SWU dikirimkan ke BWI untuk diadminstrasikan. ${ }^{21}$

Pasal 5 ayat (3) Peraturan Badan Wakaf Indonesia No.1 Tahun 2009 tentang penyetoran wakaf uang secara langsung menyatakan setelah formulir pernyataan kehendak wāqif yang berfungsi sebagai AIW yang telah diisi dan ditanda tangani wāqif dengan dilampiri bukti setoran tunai wakaf uang, selanjutnya ditandatangani oleh 2 (dua) orang petugas bank sebagai saksi dan oleh 1 (satu) orang pejabat bank sebagai PPAIW. Akan tetapi dalam prakteknya ketentuan tersebut tidak sepenuhnya dipenuhi oleh BSM selaku PPAIW. Karena dalam Formulir Wakaf Uang yang dikeluarkan oleh BSM tidak mencantumkan kolom tanda tangan 2 (dua) orang saksi, akan tetapi hanya mencantumkan kolom tanda tangan wāqif dan pejabat bank saja.

Dalam proses akad wakaf uang secara langsung di BSM, tidak mensyaratkan kehadiran nāzir, dengan memandang cukup adanya wāqif, dua orang saksi dan Pejabat Pembuat Akta Ikrar Wakaf (PPAIW) yang dalam hal adalah dari LKS-PWU BSM. Hal ini tidak sesuai dengan Pasal 2 ayat (1) Peraturan Menteri Agama No. 4 Tahun 2009 tentang Administrasi Pendaftaran Wakaf Uang yang mensyaratkan kehadiran nāzịir dalam ikrar wakaf. Pasal 2 ayat (1) PMA No.4 tahun 2009 menyatakan: Ikrar wakaf dilaksanakan oleh wāqif kepada nāzir di hadapan LKS-PWU atau notaris yang ditunjuk sebagai PPAIW dengan disaksikan oleh 2 (dua) orang saksi.

Akan tetapi apabila aturan ini diterapkan akan merepotkan nāẓir karena jumlahnya yang terbatas dan akan menghalangi proses akad apabila nāzir berhalangan hadir. Apabila wakaf uang telah tersosialisasikan ke daerah sedangkan nāzir wakafnya masih Badan Wakaf Indonesia, maka kesulitan akan bertambah, karena nāzir-nya di pusat sedangkan perwakafannya di daerah.

Kedua. Perwakafan Tidak Langsung. Mekanisme perwakafan tidak langsung atau non tunai yang terjadi di Bank Syariah Mandiri adalah calon wāqif 17.00.

${ }^{21}$ Wawancara dengan Sri Handiyani (Staf BSM Pusat) tanggal 6 Agustus 2010, jam 16.30- 
melakukan transfer wakaf uang ke rekening BWI selaku nāzir wakaf uang, dengan nomor rekening 00900 1234. Bukti transfer wakaf uang via ATM tersebut kemudian dibawa ke BSM untuk dibuatkan Sertifikat Wakaf Uang. Apabila wāqif tidak datang untuk mengambil Sertifikat Wakaf Uang, maka Sertifikat wakaf Uang tersebut kemudian dikirim kepada Badan Wakaf Indonesia (BWI).

Bentuk lain adalah calon wāqif menghubungi Bank Syariah Mandiri lewat telepon kemudian mengutarakan maksudnya untuk berwakaf uang dengan cara mendebet secara langsung sejumlah uang yang ingin diwakafkan dari rekening calon wāqif tersebut, Selanjutnya BSM menerbitkan Sertifikat Wakaf Uang. Kedua cara tersebut banyak dipilih oleh calon wäqif dalam transaksi wakaf uang non tunai karena caranya lebih mudah..$^{22}$

Selain layanan tersebut ada juga bentuk layanan dalam wakaf uang non tunai yang dapat dipergunakan oleh calon wāqif, yaitu dengan memanfaatkan layanan Inon tunai yang lain, yang dimiliki oleh BSM seperti BSM Net Banking, BSM Mobile Banking, BSM SMS Banking. ${ }^{23}$

Akan tetapi jenis layanan yang dapat dilakukan pada Media Elektronik tersebut baru berbentuk transaksi transfer kerekening tujuan di BSM, dalam hal ini rekening BWI selaku nāzir wakaf uang. Belum ada jenis layanan transaksi pembayaran wakaf seperti halnya transaksi pembayaran zakat yang telah menjadi jenis transaksi dalam media elektronik yang dimiliki oleh BSM.

Peraturan BWI No. 1 Tahun 2009 Pedoman Pengelolaan dan Pengembangan Harta Benda Wakaf Bergerak Berupa Uang mengamanatkan kepada LKSPWU untuk menyiapkan layanan transaksi wakaf non tunai, dan juga menyediakan layanan pembayaran wakaf via $e$-Banking yang tidak hanya berbentuk layanan transfer saja akan tetapi ada fitur layanan pembayaran wakaf. Pasal 4 ayat (3) Peraturan Badan Wakaf Indonesia (BWI) No.1 Tahun 2009 menyatakan: Setoran wakaf uang secara tidak langsung sebagaimana dimaksud pada ayat (1), yaitu melalui media electronic channel, antara lain: Anjungan Tunai Mandiri (ATM), Phone Banking, Internet Banking dan Mobile Banking.

\footnotetext{
17.00 .

${ }^{22}$ Wawancara dengan Sri Handiyani (Staf BSM Pusat) tanggal 6 Agustus 2010, jam 16.30-

23 http://www.syariahmandiri.co.id/category/layanan-24-jam/bsm-sms-banking/, diakses pada tanggal 25 Agustus 2010.
} 
Pada Pasal 6 Ayat (3) Peraturan Badan Wakaf Indonesi (BWI) No. 1 Tahun 2009 menyebutkan unsur-unsur apa yang disebutkan dalam $e$ Banking tersebut, yaitu: LKS-PWU wajib menyiapkan sistem on-line penerimaan wakaf uang yang menggunakan media electronic channel, yang di dalamnya mengandung informasi antara lain sebagai berikut: (1) Daftar nama nāzir yang akan dipilih wāqif; (2) Daftar denominasi wakaf uang; (3) Formulir penyataan kehendak wāqif yang berfungsi sebagai AIW; dan (4) Persetujuan setoran wakaf uang yang telah diikrarkan.

Media elektronik diadopsi oleh BWI untuk menjadi media wakaf uang yang bertujuan memudahkan calon wāqif dalam melakukan transaksi wakaf uang yang pada akhirnya bertujuan untuk menjaring dana wakaf sebesarbesarnya. Berwakaf dengan menggunakan media elektronik yang dimiliki oleh bank atau yang lebih dikenal dengan istilah $e$-Banking, merupakan wajah baru perwakafan di Indonesia.

Belum adanya fitur pembayaran wakaf sebagai mana fitur pembayaran zakat dalam e-Banking Syariah Mandiri, dikarenakan program wakaf uang ini masih baru terlaksana, mengingat BSM ditunjuk sebagai LKS-PWU baru pada tahun 2008 dan Peraturan Menteri Agama (PMA) mengenai adminstrasi pendaftaran wakaf uang diterbitkan pada 29 Juni 2009, hingga BSM belum mempersiapkan instrumen tersebut. Akan tetapi sesungguhnya BSM memiliki pengalaman dalam pembuatan instrumen tersebut yaitu dengan adanya instrumen pembayaran zakat pada layanan e-Banking BSM, yang memiliki kemiripan dengan transaksi penerimaan wakaf. Sebab lain adalah faktor dana. Karena penambahan instrumen tersebut membutuhkan dana, seperti juga sosialisasi yang harus dilakukan oleh BSM kepada publik terkait statusnya sebagai LKS-PWU.

\section{E. Investasi Wakaf Uang di LKS-PWU Bank Syariah Mandiri}

Sesuai dengan ketentuan perundang-undangan wakaf, BSM selaku LKSPWU hanya menjalankan fungsi sebagai Lembaga Penerima Wakaf Uang. Sedangkan pengelola wakaf uang tersebut adalah nāzir yang ditunjuk oleh wāqif yang dalam hal ini adalah BWI. Pada Pasal 25 Point "c" dan "d" Peraturan Pemerintah No. 42 Tahun 2006 menyatakan: LKS-PWU bertugas: (1) Menerima secara tunai wakaf uang dari wāqif atas nama nāzir; dan (2) Menempatkan uang wakaf ke dalam rekening titipan (wadi'ah) atas nama nāzir yang ditunjuk wāqif. 
Peran BSM yang hanya menjadi lembaga penerima, berbeda dengan peran yang dilakukan oleh SIBL (Social Investment Bank Limited) Bangladesh. SIBL berperan sebagai nāzir wakaf uang yang menerima, pengelola dan menyalurkan hasil dari investasi wakaf uang. Dalam pengumpulan dana wakaf uang SIBL menerbitkan Sertifikat Wakaf Uang. Sertifikat Wakaf Uang tersebut ditujukan kepada golongan kaya untuk menginvestasikan uangnya dalam bentuk wakaf dengan nominal uang wakaf yang berbeda-beda sesuai dengan kemampuannya.

SIBL menentukan peruntukkan wakaf uang tersebut sehingga calon wāqif dapat memilih sesuai dengan keinginannya peruntukkan wakaf uangnya. Apa bila diambil garis besarnya peruntukan wakaf uang tersebut meliputi empat bidang sasaran, yaitu: (1) Pemanfaatan bagi kesejahteraan pribadi dan keluarga; (2) kemanfaatan bagi kesejahteraan keluarga; (3) Pembangunan Sosial; (4) membangun masyarakat sejahtera: jaminan sosial bagi si miskin dan jaminan keamanan sosial bagi si kaya. ${ }^{24}$

Uang wakaf yang diterima SIBL disimpan dalam rekening deposito wakaf uang atas nama wāqif. Wakaf dilakukan dengan tanpa batas waktu dan rekeningnya harus terbuka dengan nama yang ditentukan oleh wāqif.25 Deposit dana wakaf tunai yang dihimpun oleh SIBL, diinvestasikan dalam berbagai bentuk investasi baik yang bersifat jangka pendek, menengah dan panjang. (1) Investasi Jangka Pendek: kredit mikro dan investasi perusahaan kecil untuk penghapusan kemiskinan dan pemberdayaan keluarga, dll. (2) Investasi Jangka Menengah: industri kerajinan, industri tenun, industri garmen, peternakan, dll. (3) Investasi Jangka Panjang: berbagai industri berat. ${ }^{26}$

SIBL memberikan peluang bagi orang-orang miskin yang memiliki usaha untuk mendapatkan bantuan pinjaman dari dana wakaf uang yang terkumpul dan juga melakukan pembimbingan usaha sehingga usaha yang dilakukan dapat mendatangkan keuntungan. Hasil dari investasi yang dilakukan oleh SIBL didistribusikan kepada 32 pos yang telah ditentukan atau sesuai dengan amanat wāqif selama tidak melanggar prinsip-prinsip syariah.

\footnotetext{
${ }^{24}$ M.A. Mannan, Sertifikat Wakaf Tunai, h. 49.

${ }^{25}$ Ibid., h. 46-47.

${ }^{26}$ Ibid., h. 40.
} 
Dalam wakaf uang di Indonesia, walaupun LKS-PWU hanya sebagai bank penerima dana wakaf uang akan tetapi peran LKS-PWU dalam investasi wakaf uang tidak bisa dihilangkan begitu saja. Karena Peraturan wakaf uang di Indonesia terutama Pasal 48 PP No. 42/2006 menetapkan penginvestasian wakaf uang hanya dapat dilakukan melalui investasi pada produk-produk LKS dan/atau instrumen keuangan syariah.

Pasal 10 Peraturan Badan Wakaf Indonesi (BWI) No. 1 Tahun 2009, menjelaskan tentang investasi wakaf uang tersebut, yaitu: (1) Investasi wakaf uang ditujukan untuk proyek-proyek produktif bagi kemaslahatan umat melalui investasi secara langsung dan tidak langsung; (2) Investasi secara langsung sebagaimana dimaksud pada ayat (1) adalah investasi pada proyekproyek yang dikelola oleh nāziri; (3) Investasi secara tidak langsung sebagaimana dimaksud pada ayat (1) adalah investasi pada lembaga yang memenuhi kriteria kelayakan kelembagaan dan menguntungkan dan (4) Investasi wakaf uang dapat dilakukan melalui deposito di Bank Syariah dengan ekspektasi bagi hasil yang paling menguntungkan.

Selanjutnya pada pasal 11 Peraturan Badan Wakaf Indonesi (BWI) No.1 Tahun 2009 dijelaskan lebih detail mekanisme investasi secara langsung, yaitu: (1) Investasi wakaf uang secara langsung pada proyek-proyek yang dikelola oleh nāzir dapat dilakukan apabila proyek tersebut memenuhi persyaratan: Usaha proyek dijalankan sesuai dengan syariah, Tingkat kelayakan proyek memenuhi syarat kelayakan proyek sesuai prinsip 5C (Character, Condition, Capital, Capacity, Collateral), dan 3P (People, Purpose, Payment) dan Sumber pengembalian dapat dihitung berdasarkan studi kelayakan. (2) Investasi wakaf uang secara langsung sebagaimana dimaksud pada ayat (1) dilakukan melalui produk dengan akad mudharabah muqayyadah di LKS dan (3) Investasi wakaf uang secara langsung sebagaimana dimaksud pada ayat (1) dijamin oleh cash collateral yang dananya diperoleh dari manfaat investasi kas wakaf yang dicadangkan sebesar 100\% (seratus persen) dari jumlah uang wakaf yang diinvestasikan atau investasi tersebut dijamin asuransi.

BWI selaku nāzir wakaf uang saat ini, melakukan dua model investasi tersebut, yaitu investasi wakaf uang secara langsung dan investasi wakaf uang secara tidak langsung. Atau dalam istilah yang lain, investasi pada sektor riil dan investasi pada sektor finansial. Investasi secara langsung atau pada sektor riil yang dilakukan oleh BWI adalah pembangunan Rumah Sakit Ibu dan Anak (RSIA). 
Rencananya pembangunan RSIA akan dibiayai dari dana wakaf produktif dengan estimasi biaya sebesar Rp. 11.251.419.600,- (sebelas miliar duaratus lima puluh satu juta empat ratus sembilan belas ribu enam ratus rupiah). Pada laporan nāzir Badan Wakaf Indonesia per 30 Juni 2010 untuk pembiayaan RSIA telah terkumpul dana Rp. 1.082.328.000,- (satu miliar delapan puluh dua juta tiga ratus dua puluh delapan ribu rupiah). Dana tersebut didapatkan dari wakaf uang sebesar Rp. 500.000.000,- (lima ratus juta rupiah) dan Bantuan Operasional Badan Wakaf Indonesia sebesar Rp. 582.328.000,- (lima ratus delapan puluh dua juta tiga ratus dua puluh delapan ribu rupiah).

Sedangkan investasi pada sektor finansial dengan menggunakan produk BSM adalah lewat produk pendanaan Giro BSM dan Deposito Syariah Mandiri.27 Dalam Laporan Nāzair BWI per 30 Juni 2010, dana yang diinvestasikan melalui Giro BSM sebesar Rp. 426.505.238,- (empat ratus dua puluh enam juta lima ratus lima ribu dua ratus tiga puluh delapan rupiah). Dan dana wakaf uang yang ditempatkan pada Deposito Bank Syariah Mandiri, dengan nilai investasi sebesar Rp. 500.000.000,- (lima ratus juta rupiah).

Dalam investasi lewat produk pembiayaan giro BSM, akad yang diterapkan adalah wadi'ah yad damanah. Hal ini berarti pihak penyimpan atau custodian adalah trustee yang sekaligus guarantor penjamin keamanan aset yang dititipkan. Ini juga berarti pihak penyimpan memiliki hak untuk menginvestasikan aset yang dititipkan. Penyimpan boleh mencampur aset penitip dengan aset penyimpan atau aset penitip yang lain dan kemudian digunakan untuk tujuan produktif mencari keuntungan. Pihak penyimpan berhak atas keuntungan yang diperoleh dari pemanfaatan aset titipan dan betanggung jawab penuh atas risiko kerugian yang mungkin timbul. Selain itu penyimpan diperbolehkan juga, atas kehendak sendiri, memberikan bonus kepada pemilik aset tanpa ada akad yang mengikat sebelumnya. ${ }^{28}$

Simpanan dengan prinsip wadi'ah yad ḍamanah mempunyai potensi masalah dalam beberapa hal, yaitu: (1) Investasi yang terbatas. Untuk me-

\footnotetext{
${ }^{27}$ Giro BSM adalah sarana penyimpanan dana yang disediakan bagi pemilik rekening dalam bentuk mata uang rupiah maupun valas dengan pengelolaan berdasarkan prinsip wadi'ah yadh dhamanah. Dengan prinsip ini, giro diperlakukan sebagai titipan yang terjaga keamanannya dan ketersediannya setiap saat guna membantu kelancaran transaksi pemilik rekening (Sumber: brosur Giro BSM).

${ }^{28}$ Ascarya, Akad dan Produk Bank Syariah (Jakarta: Raja Grafindo Persada, 2007), h. 43.
} 
lindungi kerugian modal, penyimpan (bank) tidak dapat menginvestasikan dana wadi'ah yad damanah pada proyek-proyek berisiko tinggi dengan profit tinggi sehingga penyimpan bergantung pada investasi berisiko rendah dengan profit rendah; (2) Distribusi Profit menguntungkan penyimpan. Penitip berada pada posisi belas kasihan penyimpan (bank) karena penyimpanan secara legal tidak diwajibkan untuk mendistribusi profit yang diperoleh. Bank dapat memberi hibah (bonus) rendah walaupun mereka memperoleh profit yang tinggi dan (3) Mencampur dana simpanan dengan modal. Undangundang tidak membolehkan bank syariah mencampur dana simpanan dengan modal.

Pada Pasal 25 Point 'd' Peraturan Pemerintah No. 42 Tahun 2006 menyatakan: LKS-PWU bertugas menempatkan uang wakaf ke dalam rekening titipan (wadi'ah) atas nama nāzir yang ditunjuk wāqif. Pernyataan ini bisa memunculkan kesimpulan yang berbeda, yaitu apakah yang dimaksud dengan rekening wadi'ah tersebut giro wadi'ah atau tabungan wadi'ah. Dan apakah giro wadi'ah tersebut menggunakan prinsip wadi'ah yad damanah, atau wadi'ah yad ämanah atau qard. Karena semuanya memiliki ketentuan yang berbeda-beda. Dalam wadi'ah yad damanah, bank dapat menggunakan dana titipan tersebut untuk diinvestasikan. Keuntungan yang diperoleh menjadi milik bank, penitip tidak mendapatkan apa-apa. Apabila ada hadiah itu merupakan kemurahan dari bank. Apabila terjadi kerugian dalam investasi bank wajib menanggung kerugian tersebut dan mengembalikan pokok titipan.

Adapun wadi'ah yad āmanah, bank tidak boleh menginvestasikan dana titipan melainkan hanya menjaganya saja. Bank tidak harus bertanggung jawab jika terjadi kerusakan atau kehilangan pada barang/aset titipan selama bukan karena sebab kelalaian bank. Dan biaya penitipan boleh dibebankan kepada pihak penitip sebagai konpensasi atas tanggung jawab pemeliharaan

Sedangkan giro qard, bank dianggap sebagai penerima pinjaman tanpa bunga dari nasabah deposan. Bank dapat memanfaatkan dana pinjaman tanpa bunga dari nasabah deposan untuk tujuan apa saja, termasuk untuk kegiatan produktif mencari keuntungan. Sementara itu, nasabah deposan dijamin akan memperoleh dananya secara penuh sewaktu nasabah ingin menarik dananya. Bank dapat memberikan bonus/hadiah kepada nasabah deposan selama hal tersebut tidak disyaratkan di awal.29

\footnotetext{
${ }^{29}$ Ascarya, ibid., h. 115.
} 
Selain giro BSM, BWI menginvestasikan dana wakaf uang di BSM dalam bentuk Deposito Syariah Mandiri. Deposito menggunakan bentuk mudarabah muqayyadah. Bank menginvestasikan dana nasabah kedalam proyek tertentu yang diinginkan oleh nasabah. Jangka waktu investasi dan bagi hasil disepakati bersama dan hasilnya langsung berkaitan dengan keberhasilan proyek investasi. Ada perbedaan antara giro wadi'ah dengan deposito mudarabah, sebagaimana tabel berikut ini:

Tabel 4.

Perbedaan Giro Wadi'ah dan Deposito Mudarabah

\begin{tabular}{|c|l|l|l|}
\hline No. & \multicolumn{1}{|c|}{ Keterangan } & \multicolumn{1}{|c|}{ Giro Wadi'ah } & \multicolumn{1}{|c|}{ Deposito Mudarabah } \\
\hline 1 & Sifat Dana & Titipan & Investasi \\
\hline 2 & Penarikan & $\begin{array}{l}\text { Dapat dilakukan setiap } \\
\text { saat }\end{array}$ & $\begin{array}{l}\text { Hanya dapat dilakukan } \\
\text { pada priode tertentu }\end{array}$ \\
\hline 3 & Insentif & Bonus (jika ada) & Bagi hasil \\
\hline 4 & $\begin{array}{l}\text { Pengembalian } \\
\text { modal }\end{array}$ & $\begin{array}{l}\text { Dijamin dikembalikan } \\
100 \%\end{array}$ & $\begin{array}{l}\text { Tidak dijamin dikembali- } \\
\text { kan } 100 \%\end{array}$ \\
\hline
\end{tabular}

Sumber: Dikembangkan untuk penelitian.

Adapun hasil dari investasi dana wakaf uang pada kedua produk BSM tersebut, yaitu: dari Giro BSM mendapat hasil investasi sebesar Rp. 2.169.490,- (dua juta seratus enam puluh sembilan ribu empat ratus sembilan puluh rupiah). Sedangkan hasil investasi dana wakaf uang lewat deposito adalah sebesar Rp. 6.543.812,- (enam juta lima ratus empat puluh tiga ribu delapan ratus dua belas rupiah). Hasil investasi dana wakaf uang digunakan pada bidang pendidikan, yaitu bantuan sarana pendidikan santri Pesantren Nurul Huda di Bekasi Jawa Barat yaitu sebesar Rp. 5.000.000,(lima juta rupiah). ${ }^{30}$

Tentunya ini bukan merupakan hasil yang besar. Akan tetapi BWI telah melakukan langkah-langkah penginvestasian dana wakaf uang yang dapat menjadi acuan bagi nāzir-nāzir lain yang berkecimpung dalam pengelolaan wakaf uang. Hasil investasi tentunya akan bertambah banyak apabila dana yang terkumpul bertambah banyak pula. Sehingga akan banyak sektor-sektor

${ }^{30}$ Lihat: Laporan Nazhir Badan Wakaf Indonesia per 30 Juni 2010.

Walisongo, Volume 19, Nomor 1, Mei 2011 
sosial dimasyarakat yang akan menikmati hasil investasi dana wakaf uang tersebut.

\section{F. Kesimpulan}

Dalam penggalangan dana wakaf uang, BSM telah melakukan sosialisasi pada nasabahnya melalui brosur wakaf uang. Sosialisasi tersebut sangat minim sekali mengingat media untuk bersosialisasi sangat banyak, dan BSM telah memiliki pengalaman mensosialisasikan produk-produk perbankan yang dimilikinya.

Dalam mekanisme perwakafan Uang di BSM, BSM tidak memiliki unit khusus yang melayani calon wāqif yang ingin berwakaf uang. Calon wāqif dilayani oleh customer service (CS), yang kemudian memberikan formulir Akta Ikrar Wakaf Uang untuk diisi, setelah diisi, calon wāqif membacakan Ikrar Wakaf di hadapan customer service kemudian Akta Ikrar Wakaf tersebut ditandatangani oleh Pejabat BSM setempat dan wāqif, tanpa ada kehadiran nāẓir dan saksi, serta tanpa ada tanda tangan saksi dalam Akta Ikrar Wakaf tersebut. Hal ini tidak sesuai dengan aturan yang mengamanatkan kehadiran saksi dan nāzir.

Dalam hal investasi dana wakaf uang, ada dua bentuk investasi yang telah dilakukan BWI, yaitu investasi pada sektor riil, dengan mengalokasikan dana wakaf uang yang terkumpul untuk pembangunan Rumah Sakit Ibu dan Anak (RSIA). Dan investasi pada sektor keuangan, dengan menyimpan dana wakaf uang dalam giro BSM dan diinvestasikan dalam Deposito Syariah Mandiri. Hasil dari investasi pada sektor perbankan tersebut telah disalurkan untuk membantu sarana pendidikan Pondok Pesantren Nurul Huda di Bekasi Jawa Barat. Oleh karena itu untuk meningkakan pemberdayaan wakaf tunai ada beberapa rekomendasi yang perlu dilakukan, yaitu (1) Sosialisasi wakaf uang menjadi kewajiban semua pihak. Pemerintah harus memberikan perhatian yang besar terhadap sosialisasi wakaf uang dengan mengalokasikan anggaran yang cukup untuk sosialisasi dan penggalangan wakaf uang. Pihak bank perlu lebih mengintensifkan sosialisasi wakaf uang dengan memanfaatkan layanan promosi produk yang dimilikinya; (2) LKS-PWU perlu memiliki devisi atau unit kerja yang melayani perwakafan uang dan menjalin kerjasama dengan nāẓir-nāẓir wakaf uang. Karena nāẓir wakaf uang tidak hanya 
BWI saja akan tetapi lembaga-lembaga wakaf lain yang telah memenuhi sertifikat nāzir wakaf uang; (3) BWI perlu menyiapkan standar nāzir wakaf uang profesional dan memberikan pelatihan-pelatihan nāzir wakaf profesional sehingga wakaf uang dapat berjalan sesuai dengan ketentuan dan (4) BWI perlu melakukan segera sosialisasi sertifikasi nāzir wakaf uang dan mensertifikasi nāẓir wakaf sehingga keinginan nāzir untuk mengelola wakaf uang tidak terhalangi karena belum adanya sertifikat sebagai nāzir wakaf dari BWI.

Demikianlah pokok pikiran yang dapat disampaikan dalam kesimpulan ini semoga menjadi kontribusi yang positif bagi perkembangan wakaf uang di Indonesia. $[\mathrm{w}]$ 


\section{BIBLIOGRAFI}

Ascarya, Akad dan Produk Bank Syariah, Jakarta: Raja Grafindo Perkasa, 2007.

Biro Perbankan Syariah BI dalam Mustofa Edwin dan Uswatun Hasanah (ed.), Wakaf Tunai Inovasi Finansial Islam, Peluang dan Tantangan dalam Mewujudkan Kesejahteraan Umat, Jakarta: PSTTI-IU, 2001.

Dir. Pemberdayaan Wakaf, Strategi Pengembangan Wakaf Tunai di Indonesia, Jakarta: Dir. Pemberdayaan Wakaf Departemen Agama, 2008.

Mannan, M.A., Sertifikat WakafTunai.

Suharsimi Arikunto, Prosedur Penelitian, Suatu Pendekatan Praktik, Jakarta: Rineka Cipta, 2006.

Soerjono Soekanto, Pengantar Penelitian Hukum, Jakarta: UI, 1986.

Laporan Tahunan 2009 PT. Bank Syariah Mandiri.

Laporan Nazhir Badan Wakaf Indonesia Per-30 Juni 2010.

http://www.syariahmandiri.co.id/category/info-perusahaan/profil-perusahaan /profilperusahaan-profilperusahaan/ diakses tanggal 23 Agustus 2010.

http://www.syariahmandiri.co.id/2010/05/laporan-keuangan-laz-2/, diakses tanggal 23 Agustus 2010.

http://portal.antara.co.id/berita/1252575568/wakaf-harus-uang-melalui-banksyariah

http://www.republika.co.id/berita/36558/Peran_LKS_di_Era_Wakaf_Produktif

http://www.bwi.or.id/index.php?option=com_content\&view=article\&id=654\%3 abwi-rayakanharijadiketiga\&catid=1\%3aberitawakaf\&, diakses tanggal 16 Agustus 2010.

http://www.syariahmandiri.co.id/category/layanan-24-jam/bsm-sms-banking/, diakses tanggal 25 Agustus 2010. 